Research Paper

\title{
Optimization of growth and bacteriocin production by Lactobacillus sakei subsp. sakei $2 \mathrm{a}$
}

\author{
Patrícia S. Malheiros ${ }^{1}$, Voltaire Sant'Anna ${ }^{2}$, Svetoslav D. Todorov", \\ Bernadette D.G.M. Franco ${ }^{3}$ \\ 1Departamento de Ciência de Alimentos, Universidade Federal do Rio Grande do Sul, \\ Porto Alegre, RS, Brazil. \\ ${ }^{2}$ Universidade Estadual do Rio Grande do Sul, Unidade de Encantado, Encantado, RS, Brazil. \\ ${ }^{3}$ Departamento de Alimentos e Nutrição Experimental, Universidade de São Paulo, São Paulo, SP, Brazil.
}

Submitted: October 15, 2014; Approved: November 28, 2014.

\begin{abstract}
Lactobacillus sakei subsp. sakei 2a is a bacteriocinogenic lactic acid bacterium isolated from Brazilian pork sausage, capable of inhibiting the growth of microbial pathogens, mainly Listeria monocytogenes. In order to optimize bacteriocin production for industrial applications, this study evaluated the effect of supplementation of MRS broth with glucose, Tween 20 , Tween 80 , sodium citrate, potassium chloride and cysteine, and effect of the initial $\mathrm{pH}$ and temperature of incubation of the medium on production of bacteriocins by L. sakei $2 \mathrm{a}$. Adding glucose and Tween 20 to the medium, an initial $\mathrm{pH}$ of 5.0 or 5.5 , and incubation temperatures of $25^{\circ} \mathrm{C}$ or $30^{\circ} \mathrm{C}$ resulted to the highest bacteriocin yields. Thus, a $2^{4}$ factorial design with the four variables was performed, and statistical analysis showed that it was an adequate model $\left(R^{2}=0.8296\right)$. In the studied range, the four parameters significantly influenced bacteriocin production, with the maximum yield produced at an initial $\mathrm{pH}$ between 5.5 and 7.0, a temperature between 25 and $30^{\circ} \mathrm{C}$ and supplementation of the MRS broth with glucose from 3.25 to $6.0 \mathrm{~g} \mathrm{~L}^{-1}$ and Tween 20 from 0.575 to $1.15 \%$ (v/v). Response Surface Methodology analysis indicated that the highest bacteriocin production $\left(12800 \mathrm{AU} \mathrm{mL}^{-1}\right)$ occurred in the MRS broth supplemented with $5.5 \mathrm{~g} \mathrm{~L}^{-1}$ glucose and $1.05 \%$ Tween 20 at an initial $\mathrm{pH}$ of 6.28 and an incubation temperature of $25^{\circ} \mathrm{C}$. The amount of bacteriocin produced in commercial MRS broths under the same conditions was only $5600 \mathrm{AU} \mathrm{mL}^{-1}$.
\end{abstract}

Key words: Lactobacillus sakei, bacteriocin, response surface methodology, optimization.

\section{Introduction}

Bacteriocins are antimicrobial compounds produced by many different bacterial species. They are ribosomally encoded proteinaceous molecules capable of controlling the growth of pathogenic and spoilage bacteria, and those synthesized by lactic acid bacteria (LAB) have great potential as biopreservation agents in foods (Cotter et al., 2005). Nisin, produced by Lactococcus lactis subsp. lactis, is the most intensively studied bacteriocin, and its use in foods is permitted in more than 50 countries (Field et al., 2012). However, some bacteria may acquire resistance to nisin (Davis and Adam, 1994; Garde et al., 2004) or produce proteolytic substances that inhibit its action (Garde et al., 2004; Liang et al., 2010). In this context, studying other LAB bacteriocins is essential to overcome the limitations of the typical antimicrobials used in food and pharmaceutical practices.

Lactobacillus sakei subsp. sakei 2a (L. sakei 2a), isolated from a Brazilian pork sausage sample, is capable of inhibiting the growth of $L$. monocytogenes in culture media and meat models (Martinis et al., 1998; Liserre et al., 2002). Previous studies have shown that this strain may produce three different antimicrobial compounds: sakacin $\mathrm{P}$, a $6.8 \mathrm{kDa}$ molecule identical to the $30 \mathrm{~S}$ ribosomal protein $\mathrm{S} 21$ of $L$. sakei subsp. sakei $23 \mathrm{~K}$ and a third $9.5 \mathrm{kDa}$ 
molecule identified as a histone-like DNA-binding protein HV produced by L. sakei subsp. sakei 23 (Carvalho et al., 2010).

Production of bacteriocins by LAB depends on bacterial growth and maximum activity is usually coincident with maximum cell growth (Trinetta et al., 2008). However, environmental factors such as temperature, $\mathrm{pH}$ and media composition can influence the level of bacteriocin produced (Abo-Amer et al., 2011). MRS broth remains the most widely used culture medium for growth of LAB (Todorov and Dicks, 2006). Certain components, such as carbohydrates, salts, surfactants or oxygen tension reducing agents added to the MRS broth can interfere with bacteriocin production (Vázquez et al., 2004; Todorov, 2008; Castro et al., 2011). These factors need to be evaluated to achieve optimized bacteriocin production for industrial applications.

The use of response surface methodology (RSM) has a history of successful application in many fields, especially biotechnology, and is suited for the study of the effects of distinct factors on bacteriocin production (Cladera-Olivera et al., 2004; Leães et al., 2011; Kumar et al., 2012). Studies have used RSM to evaluate the effect of medium components and environmental conditions on the antimicrobial activity of bacteriocins produced by $L$. lactis (Li et al., 2002), Micrococcus sp. GO5 (Kim et al., 2006), Lactobacillus acidophilus AA11 (Abo-Ame, 2011), Lactobacillus plantarum (Delgado et al., 2007; Han et al., 2011), and L. casei (Kumar et al., 2012).

The aim of this study was to use RSM for optimizing bacteriocin production by $L$. sakei subsp. sakei $2 \mathrm{a}$ in MRS broth using different combinations of added ingredients, $\mathrm{pH}$ levels and incubation temperatures.

\section{Materials and Methods}

\section{Bacterial cultures and media}

Bacteriocinogenic $L$. sakei subsp. sakei 2 a was grown at $30^{\circ} \mathrm{C}$ for $18 \mathrm{~h}$ in MRS broth (Difco, Detroit, MI, USA). The formulation of MRS broth per liter was Proteose Peptone (10 g), Beef Extract (10 g), Yeast Extract (5 g), Dextrose (20 g), Polysorbate 80 (1 g), Ammonium Citrate $(2 \mathrm{~g})$, Sodium Acetate $(5 \mathrm{~g})$, Magnesium Sulfate $(0.1 \mathrm{~g})$, Manganese Sulfate $(0.05 \mathrm{~g})$ and Dipotassium Phosphate $(2 \mathrm{~g})$. L monocytogenes Scott A, used as the antimicrobial activity indicator strain, was grown at $37^{\circ} \mathrm{C}$ for $24 \mathrm{~h}$ in BHI broth (Difco, Detroit, MI, USA). Both strains were stored at $-80{ }^{\circ} \mathrm{C}$ in presence of $20 \%(\mathrm{v} / \mathrm{v})$ glycerol.

\section{Antimicrobial activity determination}

The antimicrobial activity was monitored by the double layer diffusion test (Rosa et al., 2002). Shortly, plates containing agar were overlaid with $5 \mathrm{~mL}$ semi-solid BHI (BHI supplemented with $0.7 \%$ agar) containing $50 \mu \mathrm{L}$ of a fresh culture of $L$. monocytogenes Scott A $\left(10^{8} \mathrm{cfu} \mathrm{mL}^{-1}\right)$.
The plates were left to dry, and $10 \mu \mathrm{L}$ of the investigated bacteriocin diluted at 1/2,1/4,1/8,1/16, 1/32, 1/48, 1/64, $1 / 96,1 / 128,1 / 192$ and $1 / 256$ in water was spotted onto the surface. The plates were incubated at $37^{\circ} \mathrm{C}$ for $24 \mathrm{~h}$, and the bacteriocin titer was determined. A unit of bacteriocin activity (AU) was defined as the reciprocal of the highest dilution that resulted in a visible halo of inhibition. Results were expressed as AU mL ${ }^{-1}$ (Motta and Brandelli, 2002). Two independent experiments were performed, and the average was calculated.

\section{Effect of supplements in MRS broth, $\mathrm{pH}$ and temperature on bacteriocin production by $L$. sakei $2 a$}

Bacteriocin production was assessed in MRS broth (Difco, Detroit, MI, USA) supplemented with glucose (5.0 and $\left.10 \mathrm{mg} \mathrm{mL}^{-1}\right)$, Tween $20\left(10\right.$ and $\left.20 \mu \mathrm{L} \mathrm{mL}^{-1}\right)$, Tween 80 (10 and $\left.20 \mu \mathrm{L} \mathrm{mL}^{-1}\right)$, sodium citrate $\left(0.3\right.$ and $\left.1.0 \mathrm{mg} \mathrm{mL}^{-1}\right)$, potassium chloride $\left(0.55\right.$ and $\left.3 \mathrm{mg} \mathrm{mL}^{-1}\right)$, and cysteine ( 0.25 to $\left.1.0 \mathrm{mg} \mathrm{mL}^{-1}\right)$. These supplements were selected based on their previously reported influence on bacteriocin production (Vázquez et al., 2004; Todorov, 2008; Castro et al., 2011). The supplements were added to MRS broth and sterilized by autoclaving $\left(121^{\circ} \mathrm{C}\right.$ for $\left.15 \mathrm{~min}\right)$, except for cysteine which was sterilized by filtration $(0.22 \mu \mathrm{m}$, Millipore Ind. Com. Ltda, USA). Influence of the $\mathrm{pH}$ of the culture medium on bacteriocin production was determined by adjusting the initial $\mathrm{pH}$ of the MRS broth to 4.5, 5.0, 5.5 and 6.0 with sterile $1 \mathrm{~N} \mathrm{HCl}$. All tested broths were inoculated with an overnight culture of $L$. sakei $2 \mathrm{a}(1 \% \mathrm{v} / \mathrm{v})$ and incubated at $25^{\circ} \mathrm{C}$ for $18 \mathrm{~h}$. The influence of temperature on bacteriocin production was evaluated by incubating MRS broth containing $L$. sakei $2 \mathrm{a}$ at $25,30,37$ and $40{ }^{\circ} \mathrm{C}$ for $18 \mathrm{~h}$. After incubation, the $\mathrm{pH}$ of the broths was adjusted to 6.5 with $10 \mathrm{~N} \mathrm{NaOH}$ and heated at $80^{\circ} \mathrm{C}$ for $30 \mathrm{~min}$. Cells were harvested by centrifugation at $10,000 \mathrm{x}$ g for $15 \mathrm{~min}$ at $4{ }^{\circ} \mathrm{C}$, and the antimicrobial activity in the supernatant was determined as described before.

\section{Optimization of MRS supplementation using response surface methodology}

Based on results of the experiments described in the previous item, the four variables with the greatest influence on bacteriocin production (glucose, Tween 20, $\mathrm{pH}$ and temperature) were selected for application in the RSM, which was performed using a set of experimental designs, such as central composite design with five coded levels. A $2^{4}$ full factorial design for four factors with replicates at the center point and star points was used for optimization. Each variable was evaluated at five coded levels $(-\alpha,-1,0,+1,+\alpha)$. The axial distance, $\alpha$, was chosen to be 2.0 to make this design orthogonal. A set of 27 experiments were carried out. The central values ( 0 level) chosen for the experimental design were a temperature of $30{ }^{\circ} \mathrm{C}$, and initial $\mathrm{pH}$ of 6.0 , $0.55 \%$ glucose and $1.05 \%$ Tween 20 . For evaluating the 
maximum point, a second order polynomial function was fitted to the experimental results. For four factors this equation is:

$$
\begin{aligned}
& Y=b_{0}+b_{1} x_{1}+b_{2} x_{2}+b_{3} x_{3}+b_{4} x_{4}+b_{11} x_{1}^{2}+ \\
& b_{22} x_{2}{ }_{2}+b_{33} x_{3}{ }_{3}+b_{44} x_{4}{ }_{4}+b_{12} x_{1} x_{2}+b_{13} x_{1} x_{3}+ \\
& b_{14} x_{1} x_{4}+b_{24} x_{2} x_{4}+b_{34} x_{3} x_{4} b_{23} x_{2} x_{3}
\end{aligned}
$$

where: $Y$ is the response (bacteriocin production), $b_{0}$ is the intercept, $b_{1}, b_{2}, b_{3}$ and $b_{4}$ are the linear coefficients, $b_{11}, b_{22}$, $b_{33}$ and $b_{44}$ are the squared coefficients, and $b_{12}, b_{13}, b_{23}, b_{14}$, $b_{24}$ and $b_{34}$ are the interaction coefficients.

\section{Data analysis}

Results were analyzed using the Experimental Design Module of the Statistica 10.0 software (Statsoft, OK, USA). The model permitted evaluation of the effects of the linear, quadratic, and interactive terms of the independent variables on the chosen dependent variables. Three-dimensional surface plots were drawn to illustrate the main and interactive effects of the independent variables on bacteriocin production. The optimum values of the selected variables were obtained by solving the regression equation and also by analyzing the response surface contour plots. The coefficient of determination $\left(\mathrm{R}^{2}\right)$ was employed for the quality of the fit of the polynomial model equation (Cladera-Oliveira et al., 2004; Leães et al., 2011).

All experiments were conducted in triplicate, and the averages of two independent tests were calculated. Obtained values were compared using Tukey's test by Statistica 10.0, and differences were considered statistically significant when $\mathrm{p}<0.05$.

\section{Results and Discussion}

Effects of the addition of glucose, Tween 20, Tween 80 , potassium chloride, sodium citrate and cysteine to MRS broth, initial $\mathrm{pH}$ of the culture medium and the temperature of incubation on bacteriocin production by L. sakei $2 \mathrm{a}$ are shown in Table 1. The highest amount of bacteriocin was obtained in MRS broth containing glucose and Tween 20. Polysorbate surfactants, such as Tween 20 and Tween 80, suppress the adhesion of bacteriocin-producing cells, increasing the amount of bacteriocin in the culture medium. Increase of the quantity of Tween 80 in MRS broth promoted bacteriocin production by Enterococcus faecium ST311LD (Todorov and Dicks, 2005), and Tween 20 in culture broth enhanced activity of the bacteriocin produced by L. sakei/curvatus ACU-1 (Castro et al., 2011). Removal of Tween 80 from MRS broth did not affect bacteriocin production by L. sakei ST22Ch, but was critical for L. sakei ST153Ch and L. sakei ST154Ch (Todorov et al., 2013).

Bacteriocin production may be regulated by the amount of glucose in the medium. Increased bacteriocin production in the presence of glucose was recorded for $L$. plantarum AMA-K (Todorov and Dicks, 2005) and E.

\begin{tabular}{|c|c|c|}
\hline Variables & & $\begin{array}{l}\text { Bacteriocin activity } \\
\left(\mathrm{AU} \mathrm{mL} \mathrm{m}^{-1}\right)^{*}\end{array}$ \\
\hline \multirow[t]{2}{*}{ Glucose $\left(\mathrm{mg} \mathrm{mL}^{-1}\right)$} & 5.0 & $6000 \pm 800^{\mathrm{a}}$ \\
\hline & 10 & $8800 \pm 1600^{\mathrm{b}}$ \\
\hline \multirow[t]{2}{*}{ Tween $20\left(\mu \mathrm{L} \mathrm{mL}^{-1}\right)$} & 10 & $8800 \pm 1600^{\mathrm{a}}$ \\
\hline & 20 & $5600 \pm 923^{b}$ \\
\hline \multirow[t]{2}{*}{ Tween $80\left(\mu \mathrm{L} \mathrm{mL}^{-1}\right)$} & 10 & $5600 \pm 923^{\mathrm{a}}$ \\
\hline & 20 & $5200 \pm 800^{\mathrm{a}}$ \\
\hline \multirow[t]{2}{*}{ Sodium citrate $\left(\mathrm{mg} \mathrm{mL}^{-1}\right)$} & 0.3 & $2600 \pm 400^{\mathrm{a}}$ \\
\hline & 1.0 & $2600 \pm 400^{\mathrm{a}}$ \\
\hline \multirow[t]{2}{*}{ Potassium chloride $\left(\mathrm{mg} \mathrm{mL}^{-1}\right)$} & 0.55 & $2600 \pm 400^{\mathrm{a}}$ \\
\hline & 3.0 & $2600 \pm 400^{\mathrm{a}}$ \\
\hline \multirow[t]{3}{*}{ Cysteine $\left(\mathrm{mg} \mathrm{mL}^{-1}\right)$} & 0.25 & $5600 \pm 923^{\mathrm{a}}$ \\
\hline & 0.5 & $5600 \pm 923^{\mathrm{a}}$ \\
\hline & 1.0 & $3000 \pm 400^{\mathrm{b}}$ \\
\hline \multirow[t]{4}{*}{$\mathrm{pH}$} & 6.0 & $3000 \pm 400^{\mathrm{a}}$ \\
\hline & 5.5 & $6400 \pm 0^{\mathrm{b}}$ \\
\hline & 5.0 & $6400 \pm 0^{\mathrm{b}}$ \\
\hline & 4.5 & $0^{\mathrm{c}}$ \\
\hline \multirow[t]{4}{*}{ Temperature $\left({ }^{\circ} \mathrm{C}\right)$} & 25 & $3200 \pm 0^{\mathrm{a}}$ \\
\hline & 30 & $3200 \pm 0^{\mathrm{a}}$ \\
\hline & 37 & $0^{\mathrm{b}}$ \\
\hline & 40 & $0^{\mathrm{b}}$ \\
\hline
\end{tabular}

Table 1 - Variables tested for production of bacteriocin by L. sakei 2a in MRS broth.

*Mean \pm standard error of two independent experiments.

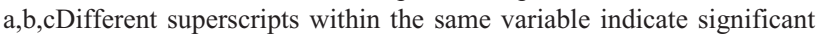
differences $(\mathrm{p}<0.05)$.

faecium ST311LD (Todorov et al., 2008). When growing L. sakei ST22Ch in MRS broth supplemented with 10,20 or $30 \mathrm{~g} \mathrm{~L}^{-1}$ glucose, the amount of bacteriocin ST22Ch produced was $1600 \mathrm{AU} \mathrm{mL} \mathrm{m}^{-1}$, and the same level of activity was recorded when glucose was replaced by $20 \mathrm{gL}^{-1}$ fructose, lactose or saccharose. However, when glucose was replaced by $20 \mathrm{~g} \mathrm{~L}^{-1}$ maltose or $20 \mathrm{~g} \mathrm{~L}^{-1}$ gluconate, a decrease in bacteriocin ST22Ch activity was recorded. These results suggest that the glucose moiety of sucrose was essential for bacteriocin production (Todorov et al., 2013).

Potassium chloride and sodium citrate are salts that influence the synthesis of antimicrobial peptides by LAB (Castro et al., 2011). However, these salts had no effect on bacteriocin production by L. sakei $2 \mathrm{a}$. On the other hand, the addition of cysteine to MRS broth increased bacteriocin production, but to a lesser extent than glucose or Tween 20 (Table 2). Cysteine is an amino acid widely used in culture media as a reducing agent to create a more favorable environment for growth of microaerophilic microorganisms such as LAB (Vázquez et al., 2004). 
Table 2 - Experimental design and results for production of bacteriocin by L. sakei 2a.

\begin{tabular}{|c|c|c|c|c|c|c|c|c|}
\hline \multirow[t]{2}{*}{ Run } & \multirow[t]{2}{*}{$\mathrm{pH}$} & \multirow{2}{*}{$\begin{array}{l}\text { Glucose } \\
\left(\mathrm{mg} \mathrm{mL}^{-1}\right)\end{array}$} & \multirow[t]{2}{*}{ Temp $\left({ }^{\circ} \mathrm{C}\right)$} & \multirow{2}{*}{$\begin{array}{l}\text { Tween } 20 \\
\left(\mu \mathrm{L} \mathrm{mL} L^{-1}\right)\end{array}$} & \multicolumn{2}{|c|}{ Bacteriocin production $\left(\mathrm{AU} \mathrm{mL}^{-1}\right)$} & \multicolumn{2}{|c|}{ Bacterial growth $\left(\log \mathrm{cfu} \mathrm{mL}^{-1}\right)$} \\
\hline & & & & & Observed & Predicted & Observed & Predicted \\
\hline 1 & $5(-1)$ & $3.25(-1)$ & $25(-1)$ & $5.75(-1)$ & $4800 \pm 0$ & 0 & $8.37 \pm 0.06$ & 6.00 \\
\hline 2 & $7(+1)$ & $3.25(-1)$ & $25(-1)$ & $5.75(-1)$ & $6080 \pm 716$ & 2959.7 & $8.72 \pm 0.07$ & 7.28 \\
\hline 3 & $5(-1)$ & $7.75(+1)$ & $25(-1)$ & $5.75(-1)$ & $3840 \pm 876$ & 1252.3 & $8.43 \pm 0.01$ & 6.00 \\
\hline 4 & $7(+1)$ & $7.75(+1)$ & $25(-1)$ & $5.75(-1)$ & $9600 \pm 0$ & 5719.7 & $8.61 \pm 0.05$ & 7.28 \\
\hline 5 & $5(-1)$ & $3.25(-1)$ & $35(+1)$ & $5.75(-1)$ & $40 \pm 55$ & 0 & $7.21 \pm 0.07$ & 5.62 \\
\hline 6 & $7(+1)$ & $3.25(-1)$ & $35(+1)$ & $5.75(-1)$ & $720 \pm 179$ & 0 & $8.02 \pm 0.02$ & 8.18 \\
\hline 7 & $5(-1)$ & $7.75(+1)$ & $35(+1)$ & $5.75(-1)$ & $360 \pm 89$ & 0 & $7.37 \pm 0.13$ & 8.46 \\
\hline 8 & $7(+1)$ & $7.75(+1)$ & $35(+1)$ & $5.75(-1)$ & $1120 \pm 438$ & 0 & $8.19 \pm 0.09$ & 8.46 \\
\hline 9 & $5(-1)$ & $3.25(-1)$ & $25(-1)$ & $15.25(+1)$ & $6400 \pm 0$ & 1252.3 & $8.33 \pm 0.06$ & 8.68 \\
\hline 10 & $7(+1)$ & $3.25(-1)$ & $25(-1)$ & $15.25(+1)$ & $9600 \pm 0$ & 5719.7 & $8.73 \pm 0.03$ & 9.26 \\
\hline 11 & $5(-1)$ & $7.75(+1)$ & $25(-1)$ & $15.25(+1)$ & $3360 \pm 1315$ & 0 & $8.30 \pm 0.05$ & 8.46 \\
\hline 12 & $7(+1)$ & $7.75(+1)$ & $25(-1)$ & $15.25(+1)$ & $4320 \pm 1073$ & 2959.7 & $8.78 \pm 0.12$ & 8.46 \\
\hline 13 & $5(-1)$ & $3.25(-1)$ & $35(+1)$ & $15.25(+1)$ & $100 \pm 0$ & 0 & $7.43 \pm 0.05$ & 8.46 \\
\hline 14 & $7(+1)$ & $3.25(-1)$ & $35(+1)$ & $15.25(+1)$ & $720 \pm 179$ & 0 & $7.93 \pm 0.04$ & 8.46 \\
\hline 15 & $5(-1)$ & $7.75(+1)$ & $35(+1)$ & $15.25(+1)$ & $100 \pm 0$ & 0 & $7.42 \pm 0.21$ & 8.46 \\
\hline 16 & $7(+1)$ & $7.75(+1)$ & $35(+1)$ & $15.25(+1)$ & $1280 \pm 438$ & 0 & $7.88 \pm 0.05$ & 6.00 \\
\hline 17 & $4(-2)$ & $5.5(0)$ & $30(0)$ & $10.5(0)$ & $200 \pm 0$ & 0 & $6.54 \pm 0.17$ & 7.28 \\
\hline 18 & $8(+2)$ & $5.5(0)$ & $30(0)$ & $10.5(0)$ & $6400 \pm 0$ & 0 & $7.89 \pm 1.11$ & 6.00 \\
\hline 19 & $6(0)$ & $1(-2)$ & $30(0)$ & $10.5(0)$ & $5760 \pm 876$ & 2329.6 & $8.55 \pm 0.09$ & 7.28 \\
\hline 20 & $6(0)$ & $10(+2)$ & $30(0)$ & $10.5(0)$ & $8960 \pm 1431$ & 2329.6 & $8.60 \pm 0.04$ & 5.62 \\
\hline 21 & $6(0)$ & $5.5(0)$ & $20(-2)$ & $10.5(0)$ & $4800 \pm 0$ & 1402.4 & $8.73 \pm 0.19$ & 8.18 \\
\hline 22 & $6(0)$ & $5.5(0)$ & $40(+2)$ & $10.5(0)$ & $200 \pm 0$ & 0 & $6.40 \pm 0.24$ & 8.46 \\
\hline 23 & $6(0)$ & $5.5(0)$ & $30(0)$ & $1.0(-2)$ & 4480715 & 1689.6 & $8.40 \pm 0.13$ & 8.46 \\
\hline 24 & $6(0)$ & $5.5(0)$ & $30(0)$ & $20.0(+2)$ & $9600 \pm 0$ & 1689.6 & $8.67 \pm 0.17$ & 8.68 \\
\hline 25 & $6(0)$ & $5.5(0)$ & $30(0)$ & $10.5(0)$ & $9600 \pm 0$ & 10026.4 & $8.42 \pm 0.10$ & 8.46 \\
\hline 26 & $6(0)$ & $5.5(0)$ & $30(0)$ & $10.5(0)$ & $9600 \pm 0$ & 10026.4 & $8.45 \pm 0.11$ & 8.46 \\
\hline 27 & $6(0)$ & $5.5(0)$ & $30(0)$ & $10.5(0)$ & $10880 \pm 1752$ & 10026.4 & $8.45 \pm 0.11$ & 8.46 \\
\hline
\end{tabular}

Higher amounts of bacteriocin were produced when the $\mathrm{pH}$ of the MRS broth was 5.0 or 5.5 and the incubation temperature was $25{ }^{\circ} \mathrm{C}$ or $30^{\circ} \mathrm{C}$. At temperatures above $37^{\circ} \mathrm{C}$ and $\mathrm{pH}$ below 4.5 , the detected amount of bacteriocin was negligible. Similar results were reported for bacteriocin production by L. acidophilus AA11 in M17 broth supplemented with 0.5\% lactose (Abo-Amer, 2011). Conversely, production of bacteriocin by L. sakei ST22Ch in MRS broth at pH 5.0 and 5.5 was 50\% lower than that produced when the initial $\mathrm{pH}$ ranged from 5.5 to 6.0. At a $\mathrm{pH}$ of 4.5 , very low growth and production of bacteriocin were detected (Todorov et al., 2013). The optimal temperature and initial $\mathrm{pH}$ for bacteriocin production by Micrococcus sp. GO5 were $37{ }^{\circ} \mathrm{C}$ and 7.0-9.0, respectively (Kim et al., 2006). In general, $\mathrm{pH}$ is important for bacteriocin production because it affects the aggregation of the producing cells and the adsorption of bacteriocin to their surface.
The $\mathrm{pH}$ also has an important role in the proteolytic degradation of bacteriocins (Cheigh et al., 2002).

The initial $\mathrm{pH}$ of the MRS broth, incubation temperature and concentration of Tween 20 and glucose in the medium were the factors with the most significant influence on bacteriocin production by L. sakei 2a (Table 2), and were selected for the RSM analysis.

Table 3 presents the results of the analysis of variance (ANOVA) employed for determining the significant parameters and for estimating the production of bacteriocin by $L$. sakei $2 \mathrm{a}$ as a function of these four variables. The resulting regression equation presented a determination coefficient $\left(\mathrm{R}^{2}\right)$ of 0.8296 , and a non-significant $(\mathrm{p}>0.05)$ test of lack of fit, indicating that $82.96 \%$ of the total variation was explained by the model. In addition, the calculated $F$-value model was 5.3 , which is twice as high as the $F$-value for $95 \%$ confidence $\left(F t_{9,8}=2.4\right)$ found in statistical 
Table 3 - Analysis of variance for the model estimated for production of bacteriocin by L. sakei 2a.

\begin{tabular}{lccccc}
\hline Source & Sum of squares & Degrees of freedom & Mean square & $F$-value & p-value \\
\hline $\mathrm{pH}(\mathrm{L})$ & 30016067 & 1 & 30016067 & 54.9611 & $0.0177^{*}$ \\
$\mathrm{pH}(\mathrm{Q})$ & 83388981 & 1 & 83388981 & 152.6898 & $0.0064^{*}$ \\
Glucose (L) & 153600 & 1 & 153600 & 0.2813 & 0.6488 \\
Glucose (Q) & 19746226 & 1 & 19746226 & 36.1564 & $0.0265^{*}$ \\
Temperature (L) & 115984067 & 1 & 115984067 & 212.3732 & $0.0046^{*}$ \\
Temperature (Q) & 101113426 & 1 & 101113426 & 185.1442 & $0.0053^{*}$ \\
Tween 20 (L) & 3808067 & 1 & 3808067 & 6.9728 & 0.1184 \\
Tween 20 (Q) & 23166670 & 1 & 23166670 & 42.4194 & $0.0227^{*}$ \\
pH by Glucose & 518400 & 1 & 518400 & 0.9492 & 0.4326 \\
pH by Temperature & 3960100 & 1 & 3960100 & 7.2512 & 0.1146 \\
pH by Tween 20 & 396900 & 1 & 396900 & 0.7267 & 0.4837 \\
Glucose by Temperature & 3097600 & 1 & 3097600 & 5.6719 & 0.1401 \\
Glucose by Tween 20 & 7617600 & 1 & 7617600 & 13.9482 & 0.0648 \\
Temperature by Tween 20 & 22500 & 1 & 22500 & 0.0412 & 0.8579 \\
Lack of fit & 61401033 & 10 & 6140103 & 11.2429 & 0.0843 \\
Pure Error & 1092267 & 2 & 546133 & & \\
Total Some of Square & 366924119 & 26 & & & \\
\hline
\end{tabular}

*statistically significant $(\mathrm{p}<0.05)$.

$(\mathrm{L})$ : linear effect; (Q): quadratic effect.

tables and demonstrates the significance of the regression model. Analysis of variance also indicated that the smaller the $P$-value, the more significant the corresponding coefficient. For the production of antimicrobial peptides by $L$. sakei $2 \mathrm{a}$, linear and quadratic effects of $\mathrm{pH}$ and temperature were significant $\left(P_{\mathrm{T}}, P_{\mathrm{T}-\mathrm{T}}, P_{\mathrm{pH}}, \mathrm{P}_{\mathrm{pH}-\mathrm{pH}}<0.05\right)$. The quadratic effects of the glucose and Tween 20 concentrations $\left(P_{\text {Glu- }}\right.$ cose-Glucose, $\left.P_{\text {Tween20-Tween } 20}<0.05, P_{\mathrm{pH}-\mathrm{pH}}<0.05\right)$ indicated that they can act as limiting factors, and variation in their values will alter bacteriocin activity to a considerable extent. The interaction of glucose and Tween 20 concentration was also significant in predicting bacteriocin production with $93 \%$ confidence Thus, the following equation was obtained:

$$
\begin{aligned}
& Y=10026.7+2233.7 x_{1}-3954.2 x_{1}^{2}-1924.2 x_{2}^{2}- \\
& 4396.7 x_{3}-4354.2 x_{3}^{2}-2084.2 x_{4}^{2}-1380 x_{2} x_{4}
\end{aligned}
$$

The "one-at-a time" optimization technique is massive, time consuming and usually ignores the importance of interactions between the process variables. In the statistical regression equations, positive constants in the linear effects indicate that higher values of the variable enhance bacteriocin production, and negative parameters indicate that the variable reduces or inhibits bacteriocin production. Also, significant quadratic parameters contribute to the curvature of the contour curve, giving a concavity to the graphic (downward if the variable constant is negative and upward if the variable constant is positive), and consequently the studied variable has an optimal point. In this context, RSM is a powerful tool for optimizing biotechnological processes (Anthony et al., 2009; Leães et al., 2011). The three-dimensional response surface curves obtained by plotting the above equation are shown in Figure 1. Equation 2 shows that the four variables have significant negative quadratic effects, and graphical analysis show downward concavity, and thus glucose, $\mathrm{pH}$, temperature and Tween 20 concentration produce optimal bacteriocin production (Figure 1). In the range studied, ANOVA (Table 3) results show that the four variables had a significant effect on bacteriocin production. Response surface data showed maximum bacteriocin production at an initial $\mathrm{pH}$ between 5.5 and 7.0, a temperature between 25 and $30{ }^{\circ} \mathrm{C}$ and supplementation of MRS broth with glucose and Tween 20 in the range of 3.25 to $6.0 \mathrm{~g} \mathrm{~L}^{-1}$ and 0.575 to $1.15 \%(\mathrm{v} / \mathrm{v})$, respectively. The addition of glucose and Tween 20 to MRS broth for all concentrations tested increased the yield of bacteriocin production compared with the control MRS broth at 25 or $30{ }^{\circ} \mathrm{C}$. According to Kumar et al. (2012), the $\mathrm{pH}$ and temperature were effective for bacteriocin production by $L$. casei LA-1 ranging of 6.8 to 7.2 and 33.5 to $34.5^{\circ} \mathrm{C}$, respectively. Lee et al. (2012) also showed that glucose concentration and initial $\mathrm{pH}$ had a large influence on the production of bacteriocins by Lactobacillus brevis DF01.

The effects of $\mathrm{pH}$ and temperature are very important for bacteriocin production, as reported for bacteriocins produced by L. mesenteroides FR52 (Krier et al., 1998), L. plantarum 17.2b (Delgado et al., 2007), and Bacillus spp. P11 (Leães et al., 2011), among others. Using the RSM 

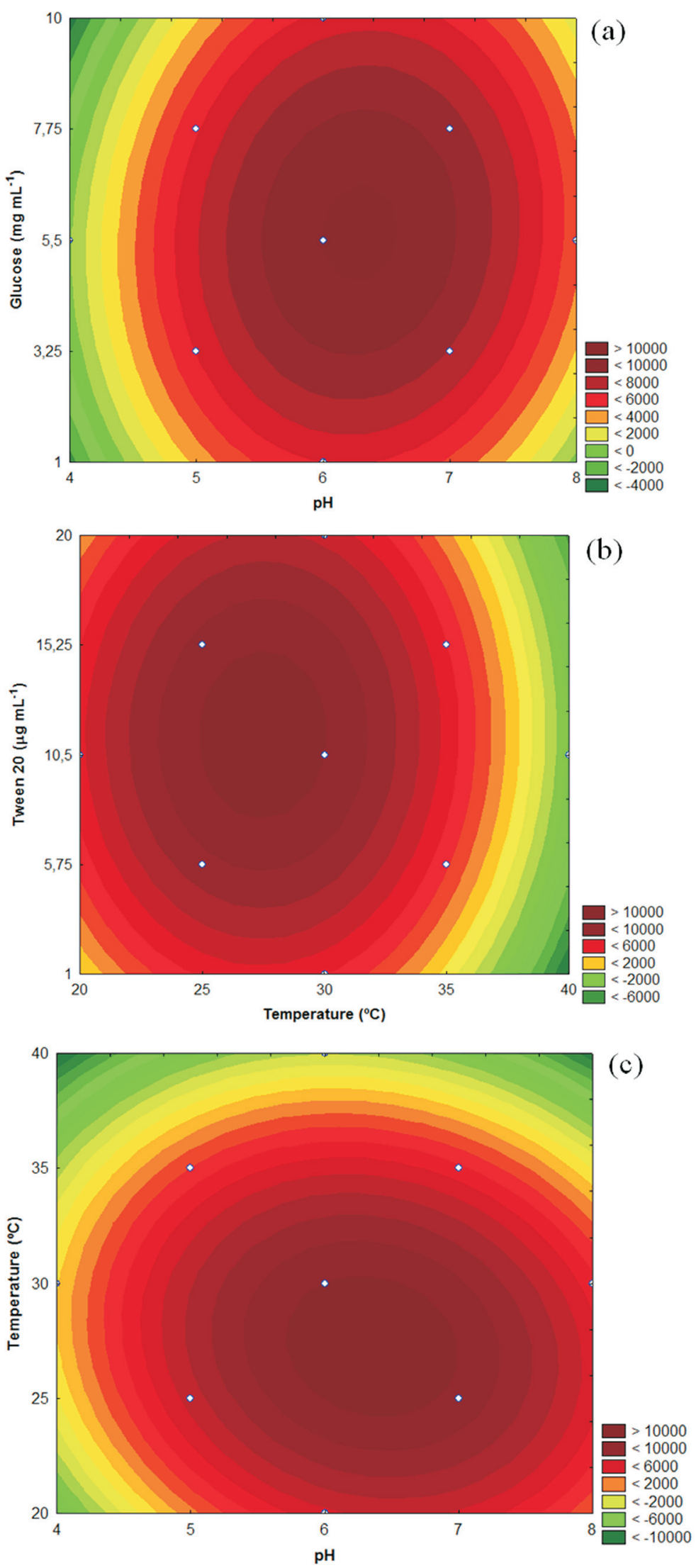

Figure 1 - Response surface of bacteriocin production $\left(\mathrm{AU} \mathrm{mL}^{-1}\right)$ by $L$. sakei $2 \mathrm{a}$ in MRS broth as a function of (a) glucose concentration ( $\mathrm{mg} \mathrm{mL}^{-1}$ ) and initial $\mathrm{pH}$; (b) Tween 20 concentration $\left(\mu \mathrm{L} \mathrm{mL}^{-1}\right)$ and temperature $\left({ }^{\circ} \mathrm{C}\right)$; (c) temperature $\left({ }^{\circ} \mathrm{C}\right)$ and initial $\mathrm{pH}$. 
methodology, it was possible to demonstrate that these parameters are also fundamental for bacteriocin production by $L$. sakei $2 \mathrm{a}$, beyond the supplementation of MRS broth with glucose and Tween 20. Glucose, an important carbon source, may both induce and inhibit the activity of bacteriocins in a strain-dependent manner (Todorov, 2008; Abo-Amer et al., 2011). A L. plantarum AMA-K medium supplemented with glucose induced the synthesis of bacteriocin (Todorov, 2008), as was also detected in the present work. Likewise, MRS broth supplemented with Tween 20 enhanced $L$. curvatus/L. curvatus ACU-1 bacteriocin activity (Castro et al., 2011). Tween 20 is a non-ionic surfactant agent capable of increasing bacteriocin production due to its effect on membrane fluidity and stimulation of the secretion of proteins (Reese and Maguire, 1969).

According to the analysis of variance and Fischer's test results (Table 4), the obtained regression equation for growth of $L$. sakei 2 a indicated that the calculated $F$-value was 19.3, which is eight times higher than the tabulated $F$-value (2.4). The $\mathrm{R}^{2}$-value estimated for the regression model was 0.9577 , with a non-significant $(\mathrm{p}>0.05)$ of test of lack of fit. The quadratic and linear effects of $\mathrm{pH}$ and temperature on growth of L. sakei $2 \mathrm{a}$, as indicated by ANOVA, were significant $(p<0.05)$, leading to the following equation:

$$
Y=8.46+0.64 x_{1}-0.39 x_{1}^{2}-0.99 x_{3}-0.44 x_{3}^{2}
$$

The three-dimensional response surface of $L$. sakei $2 \mathrm{a}$ growth as a function of the initial $\mathrm{pH}$ and incubation tem- perature is shown in Figure 2. Response surface data showed maximum growth at an initial $\mathrm{pH}$ between 5.5 and 7.5 and a temperature between 20 and $30^{\circ} \mathrm{C}$. Therefore, the optimum condition for growth of $L$. sakei $2 \mathrm{a}$ is within the range of optimal production of bacteriocin. Mataragas et al. (2003) demonstrated that decreasing the temperature below the optimum for growth improved bacteriocin production. A high correlation between biomass production and bacteriocin synthesis was reported for L. lactis (De Vuyst, 1995), Brevibacterium linens (Motta and Brandelli, 2003) and L. casei LA-1 (Kumar et al., 2012). However, many studies performed with other LAB have shown that the optimal conditions for bacteriocin production are different than those for optimal growth (Li et al., 2002; Mataragas et al., 2003; Abo-Amer, 2011). Therefore, these parameters must be evaluated case-by-case and be considered straindependent.

By mathematical optimization (from setting the first derivative equal to zero with respect to each variable), the best conditions for bacteriocin production are: an initial $\mathrm{pH}$ of 6.28, a temperature of $25^{\circ} \mathrm{C}$, glucose concentration of $5.5 \mathrm{mg} \mathrm{mL}^{-1}$ and Tween 20 concentration of $10.5 \mu \mathrm{L} \mathrm{mL}^{-1}$. Under these conditions, L. sakei 2a produced more then 2 time more bacteriocin $\left(12800 \mathrm{AU} \mathrm{mL}^{-1}\right)$ than in the nonoptimized counterpart (5600 AU mL $\mathrm{AL}^{-1}$ ) (Figure 3). The highest production of bacteriocin occurred after $12 \mathrm{~h}$ of incubation, coinciding with the early stationary phase of growth. Similar trends were reported previously for other bacteriocinogenic L. sakei strains (Leroy and De Vuyst,

Table 4 - Analysis of variance for the model and the regression coefficients estimated for production of bacteriocin by L. sakei 2a.

\begin{tabular}{lccccc}
\hline Source & Sum of squares & Degrees of freedom & Mean square & $F$-value & p-value \\
\hline $\mathrm{pH}(\mathrm{L})$ & 2.723 & 1 & 2.7235 & 138.3285 & $0.0071^{*}$ \\
$\mathrm{pH}(\mathrm{Q})$ & 0.794 & 1 & 0.79483 & 40.3690 & $0.0238^{*}$ \\
Glucose (L) & 0.00039 & 1 & 0.00039 & 0.0199 & 0.9007 \\
Glucose (Q) & 0.0156 & 1 & 0.0156 & 0.7957 & 0.4664 \\
Temperature (L) & 5.839 & 1 & 5.8393 & 296.5763 & $0.0033^{*}$ \\
Temperature (Q) & 1.021 & 1 & 1.0212 & 51.8668 & $0.0187^{*}$ \\
Tween 20 (L) & 0.00008 & 1 & 0.000085 & 0.0043 & 0.9536 \\
Tween 20 (Q) & 0.00584 & 1 & 0.0058 & 0.2964 & 0.6407 \\
pH by Glucose & 0.00361 & 1 & 0.0036 & 0.1834 & 0.7101 \\
pH by Temperature & 0.1623 & 1 & 0.1623 & 8.2442 & 0.1029 \\
pH by Tween 20 & 0.00000 & 1 & 0.000000 & 0.0000 & 0.9990 \\
Glucose by Temperature & 0.00189 & 1 & 0.00189 & 0.0962 & 0.7858 \\
Glucose by Tween 20 & 0.00441 & 1 & 0.00440 & 0.2239 & 0.6827 \\
Temperature by Tween 20 & 0.00001 & 1 & 0.000007 & 0.0004 & 0.9866 \\
Lack of fit & 0.4302 & 10 & 0.0430 & 2.1851 & 0.3546 \\
Pure Error & 0.0393 & 2 & 0.0196 & & \\
Total Some of Square & 11.1028 & 26 & &
\end{tabular}

*statistically significant $(\mathrm{P}<0.05)$.

(L): linear effect; (Q): quadratic effect. 


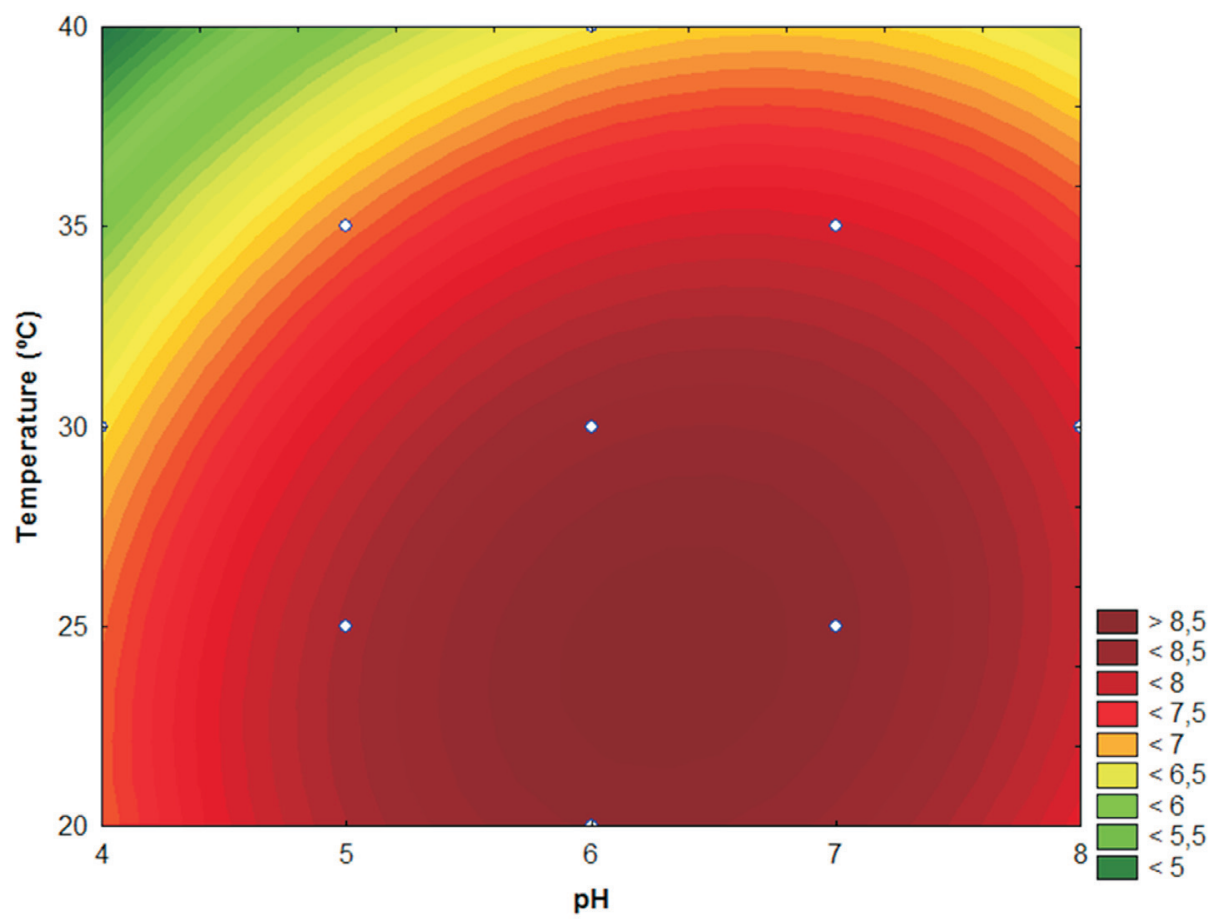

Figure 2 - Response surface of $L$. sakei 2a growth $\left(\log \mathrm{cfu} \mathrm{mL}^{-1}\right)$ in MRS broth as a function of temperature $\left({ }^{\circ} \mathrm{C}\right)$ and initial $\mathrm{pH}$.

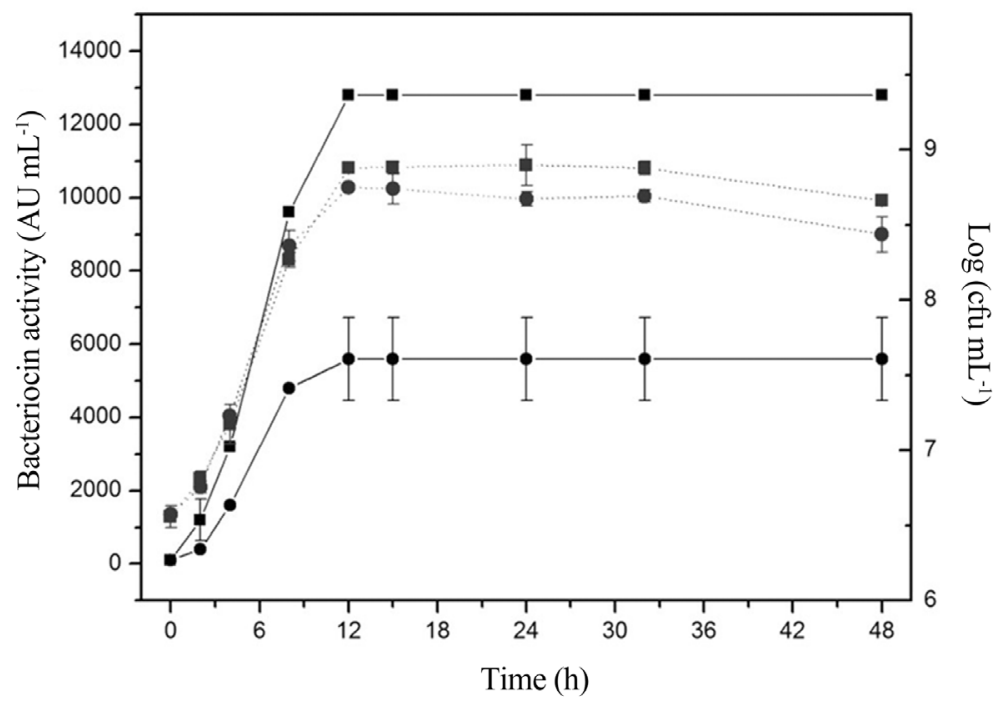

Figure 3 - Bacteriocin activity (-) and bacterial growth (...) of $L$. sakei 2a in MRS broth supplemented with glucose (5.5 mg mL-1) and Tween 20 $\left(10.5 \mu \mathrm{L} \mathrm{mL}^{-1}\right)$ at optimal conditions of temperature $\left(25^{\circ} \mathrm{C}\right)$ and initial $\mathrm{pH}(6.28)(\bullet)$ or in a commercial MRS broth (Difco) control ( $\left.\mathbf{\square}\right)$. Each point represents the mean \pm standard error of two independent experiments.

2003) and for bacteriocin-like inhibitory substances from L. sakei/L. curvatus ACU-1 (Castro et al., 2011). Because the antimicrobial activity started at the exponential growth phase and reached maximum values at the stationary phase, it is reasonable to consider bacteriocin a primary metabolite (Cheikhyoussef et al., 2009; Todorov and Dicks, 2009). The activity of bacteriocin remained unaltered for $48 \mathrm{~h}$ of incubation at $25^{\circ} \mathrm{C}$, suggesting that extracellular proteases were not produced.

\section{Conclusion}

Supplementation of MRS broth with glucose and Tween 20 increased the production of bacteriocin by $L$. sakei $2 \mathrm{a}$. A RSM indicated that maximum bacteriocin pro- 
duction in MRS broth was achieved at an initial $\mathrm{pH}$ of 6.28, an incubation temperature of $25^{\circ} \mathrm{C}$, a glucose concentration of $5.5 \mathrm{mg} \mathrm{mL}^{-1}$ and a Tween 20 concentration of $10.5 \mu \mathrm{L} \mathrm{mL}^{-1}$. L. sakei 2a reached the stationary phase after $12 \mathrm{~h}$ of cultivation, coinciding with maximum bacteriocin yield. These parameters are important for the optimization of growth and bacteriocin production, essential for the use of this strain or its bacteriocins as biopreservation agents for industrial applications.

\section{Acknowledgments} CNPq.

The study was supported by FAPESP, CAPES and

\section{References}

Abo-Amer AE (2011) Optimization of bacteriocin production by Lactobacillus acidophilus AA11, a strain isolated from Egyptian cheese. Ann Microbiol 61:445-452.

Anthony T, Rajesh T, Kayalvizhi N et al. (2009) Influence of medium components and fermentation conditions on the production of bacteriocin(s) by Bacillus licheniformis AnBa9. Biores Technol 100:872-877.

Carvalho KG, Bambirra FHS, Kruger MF et al. (2010) Antimicrobial compounds produced by Lactobacillus sakei subsp. sakei $2 \mathrm{a}$, a bacteriocinogenic strain isolated from a Brazilian meat product. J Ind Microbiol Biotechnol 37:381-390.

Castro MP, Palavecino NZ, Herman CO et al. (2011) Lactic acid bacteria isolated from artisanal dry sausages: Characterization of antibacterial compounds and study of the factors affecting bacteriocin production. Meat Sci 87:321-329.

Cheigh CI, Choi HJ, Park H et al. (2002) Influence of growth conditions on the production of a nisin-like bacteriocin by Lactococcus lactis subsp. lactis A164 isolated from kimchi. J Biotech 95:225-235.

Cheikhyoussef A, Pogori N, Chen H et al. (2009) Antimicrobial activity and partial characterization of bacteriocin-like inhibitory substances (BLIS) produced by Bifidobacterium infantis BCRC 14602. Food Control 20:553-559.

Cladera-Oliveira F, Caron GR, Brandelli A (2004) Bacteriocin production by Bacillus licheniformis strain P40 in cheese whey using response surface methodology. Bioch Eng J 21:53-58.

Cotter PD, Hill C, Ross P (2005) Bacteriocins: developing innate immunity for food. Nat Rev Microbiol 3:777-788.

Davies EA, Adams MR (1994) Resistance of Listeria monocytogenes to the bacteriocin nisin. Int J Food Microbiol 21:341-347.

De Vuyst L (1995) Nutritional factors affecting nisin production by Lactococcus lactis subsp. lactis NIZO 22186 in a synthetic medium. J Appl Bacteriol 78:28-33.

Delgado A, López FNA, Brito D et al. (2007) Optimum bacteriocin production by Lactobacillus plantarum $17.2 \mathrm{~b}$ requires absence of $\mathrm{NaCl}$ and apparently follows a mixed metabolite kinetics. J Biotechnol 130:193-201.

Field D, Begley M, O'Connor PM et al. (2012) Bioengineered nisin A derivatives with enhanced activity against both
Gram positive and Gram negative pathogens. Plos One 7:112.

Garde S, Ávila M, MEDINA M et al. (2004) Fast induction of nisin resistance in Streptococcus thermophilus INIA 463 during growth in milk. Int J Food Microbiol 96:165-172.

Han B, Yu Z, Liu B et al. (2011) Optimization of bacteriocin production by Lactobacillus plantarum YJG, isolated from the mucosa of the gut of healthy chickens. Afr J Microbiol Res 5:1147-1155.

Kim MH, Kong YJ, Baek H et al. (2006) Optimization of culture conditions and medium composition for the production of micrococcin GO5 by Micrococcus sp. GO5. J Biotechnol 121:54-61.

Krier F, Revol-Junelles AM, Germain P (1998) Influence of temperature and $\mathrm{pH}$ on production of two bacteriocins by Leuconostoc mesenteroides subsp mesenteroides FR52 during batch fermentation. Appl Microbiol Biotechnol 50:359363.

Kumar M, Jain AK, Ghosh M et al. (2012) Statistical Optimization of Physical Parameters for Enhanced Bacteriocin Production by L. casei. Biotechnol Bioprocess Eng 17:606-616.

Leães FL, Sant'Anna V, Vanin NG et al. (2011) Use of byproducts of food industry for production of antimicrobial activity by Bacillus sp. P11. Food Bioprocess Technol 4:822-828.

Lee YM, Kim JS, Kim WJ (2012) Optimization for the Maximum Bacteriocin Production of Lactobacillus brevis DF01 Using Response Surface M'ethodology. Food Sci Biotechnol 21:653-659.

Leroy F, De Vuyst L (1999) Temperature and $\mathrm{pH}$ conditions that prevail during fermentation of sausages are optimal for production of antilisterial bacteriocin Sakacin K. Appl Environ Microbiol 65:974-981.

Li C, Bai J, Cai Z et al. (2002) Optimization of a cultural medium for bacteriocin production by Lactococcus lactis using response surface methodology. J Biotechnol 93:27-34.

Liang X, Sun Z, Zhong J et al. (2010) Adverse effect of nisin resistance protein on nisin-induced expression system in Lactococcus lactis. Microbiol Res 165:458-465.

Liserre AM, Landgraf M, Destro MT et al. (2002) Inhibition of Listeria monocytogenes by a bacteriocinogenic Lactobacillus sake strain in modified atmosphere-packaged Brazilian sausage. Meat Sci 61:449-455.

Martinis ECP, Franco BDGM (1998) Inhibition of Listeria monocytogenes in a pork product by a Lactobacillus sake strain. Int J Food Microbiol 42:119-126.

Mataragas M, Metaxopolous J, Galiotou M et al. (2003) Influence of $\mathrm{pH}$ and temperature on growth and bacteriocin production by Leuconostoc mesenteroides L124 and Lactobacillus curvatus L442. Meat Sci 64:265-271.

Motta AS, Brandelli A (2002) Characterization of an antimicrobial peptide produced by Brevibacterium linens. J Appl Microbiol 92:63-70.

Motta AS, Brandelli A (2003) Influence of growth conditions on bacteriocin production by Brevibacterium linens. Appl Microbiol Biotechnol 62:163-167.

Reese ET, Maguire A (1969) Surfactants as stimulants of enzyme production by microorganisms. Appl Microbiol 17:242-245.

Rosa CM, Franco BDGM, Montville TM et al. (2002) Purification and mechanistic action of a bacteriocin produced by a Brazilian sausage isolate. Lactobacillus sake 2a. J Food Saf 22:39-54. 
Todorov SD, Dicks LMT (2005) Optimization of bacteriocin ST311LD production by Enterococcus faecium ST311LD, isolated from spoiled black olives. J Microbiol 43:370-374.

Todorov SD, Dicks LMT (2006) Effect of medium components on bacteriocin production by Lactobacillus plantarum strains ST23LD and ST341LD, isolated from spoiled olive brine. Microbiol Res 161:102-108.

Todorov SD (2008) Bacteriocin production by Lactobacillus plantarum AMA-K isolated from Amasi, a zimbabwean fermented milk product and study of the adsorption of bacteriocin AMA-K to Listeria $s p$. Braz J Microbiol 39:178-187.

Todorov SD, Dicks LMT (2009) Bacteriocin production by Pediococcus pentosaceous isolated from marula (Scerocarya birrea). Int J Food Microbiol 132:117-126.
Todorov SD, Vaz-Velho M, Franco BDGM et al. (2013) Partial characterization of bacteriocins produced by three strains of Lactobacillus sakei, isolated from salpicao, a fermented meat product from North-West of Portugal. Food Control 30:111-121.

Trinetta V, Rollini M, Manzoni M (2008) Development of a low cost culture medium for sakacin A production by L. sakei. Process Biochem 43:1275-1280.

Vázquez JA, Cabo ML, González MP et al. (2004) The role of amino acids in nisin and pediocin production by two lactic acid bacteria A factorial study. Enzyme Microb Technol $34: 319-325$

Associate Editor: Elaine Cristina Pereira De Martinis

All the content of the journal, except where otherwise noted, is licensed under a Creative Commons License CC BY-NC. 